\author{
RADOSŁAW NAWROCKI \\ Uniwersytet im. Adama Mickiewicza \\ $w$ Poznaniu
}

\title{
O OSOBLIWOŚCIACH DYSKURSÓW W EDUKACJI
}

\begin{abstract}
Nawrocki Radosław, O osobliwościach dyskursów w edukacji [About Curiosities of Discourses in Education]. Studia Edukacyjne nr 51, 2018, Poznań 2018, pp. 427-436. Adam Mickiewicz University Press. ISSN 1233-6688. DOI: 10.14746/se.2018.51.25

The basic goal of the text is to follow the work strategy on selected pedagogical concepts as part of creating educational discourses. I assume that within the framework of the functioning of discursive practices in education, a certain work is done, which flattens the conceptual grid regarding education. Thus, these concepts are unambiguous, boil down to the most direct, superficial and obvious meaning. The way of thinking about education, present in the dominant discourses located in the social circulation, causes that educational processes are devoid of meaning wealth. This is how it sets the playing field in thinking about education, designing educational policy and educational practice. The treatment, which is to restore the educational discourses to depth, aporethism, internal struggle, the element of contradiction is to launch a specific etymological work that reveals the fuller meaning of the basic concepts that build the educational imagination. Thanks to this, a certain contrast will also be created between the extracted meaning and those meanings that are promoted in the most varied discursive practices launched in the field of education
\end{abstract}

Key words: discourse, paradigm, education, philosophy of education

Podstawowym celem tekstu jest analiza strategii pracy nad wybranymi pojęciami pedagogicznymi pojawiającymi się $\mathrm{w}$ ramach tworzenia dyskursów edukacyjnych. Wychodzę z założenia, że w obrębie funkcjonowania praktyk dyskursywnych $\mathrm{w}$ edukacji wykonuje się (często nieświadomie) pewną pracę, która spłaszcza siatkę pojęciową dotyczącą edukacji. Tym samym, czyni się te pojęcia jednoznacznymi, sprowadza je do najbardziej bezpośredniego, powierzchownego i oczywistego znaczenia. Sposób myślenia o edukacji, obecny w dominujących dyskursach ulokowanych w krwiobiegu społecznym, powoduje, że procesy edukacyjne pozbawione są bogactwa znaczeniowego. To niejako ustawia pole gry w myśleniu o edukacji, projektowa- 
niu polityki oświatowej i praktyki edukacyjnej. Zabiegiem, który ma według mnie zdolność przywracania dyskursom edukacyjnym głębię, aporetyczność, wewnętrzną walkę, pierwiastek sprzeczności jest uruchomienie swoistej pracy etymologicznej, która odsłoni pełniejsze znaczenie podstawowych pojęć budujących wyobraźnię edukacyjną. Dzięki temu pojawi się szansa na wytworzenie także pewnego kontrastu pomiędzy wydobytym znaczeniem a promowanymi w najróżniejszych praktykach dyskursywnych uruchamianych na polu edukacji.

Pracę etymologiczną pozwalającą sięgać do źródeł nie czyni wartościową sam fakt sięgania do początków. Samo zbliżanie się do źródeł pojęć nie czyni rozumienia bardziej życiodajnym i pełnym, a oddalanie od nich nie skazuje nas na porażkę $\mathrm{w}$ rozumieniu i używaniu pojęć. Sprawa nie jest tak prosta i banalna, bowiem nie o sięganie do źródeł tu chodzi, ale o szukanie znaczeń, interpretacji ożywiających pojęcia. Tak się składa, że przyjmując taką strategię, nierzadko zbliżamy się do etymologii określonych pojęć.

Aby zrozumieć sens wykonywania takiej pracy etymologicznej, należy zaproponować inne, mniej oczywiste wyjaśnienie. Strategią wartą w tym kontekście uwagi i wiele rozjaśniającą jest ta zaproponowana przez Blumenberga. Paulina Sosnowska pisze w tym kontekście:

tu pojawia się kategoria „ponownego obsadzenia” pozycji opuszczonych przez dawne odpowiedzi: chodzi o to, że nowa epoka w dziejach musi niejako na nowo wypełnić puste miejsce, zwolnione przez poprzedni paradygmat, udzielić zupełnie nowych odpowiedzi na wyzwania, którym dawny paradygmat nie potrafił już sprostać ${ }^{\text {. }}$

Praca na polu dyskursywnym jest pracą detektywistyczną, czynioną w trybie poszukiwania znaczeń, które oddają w sposób maksymalnie optymalny złożoność naszych doświadczeń oraz - poprzez performatywną funkcję języka - pozwalają takie doświadczenia uruchamiać. Ze względu na dominującą logikę kulturową charakterystyczną dla nowoczesności, a cechującą się swoistym spłaszczaniem, instrumentalizowaniem, ideologizowaniem pojęć, fortunnym i przydatnym zabiegiem w budowaniu dyskursów (m.in. edukacyjnych) jest zatem sięganie do etymologii bądź mniej popularnych znaczeń określonych pojęć. Nie jest to jednak praca bezwiedna, zaledwie archeologiczna, ale praca twórcza zderzająca wybrane interpretacje ze specyfiką kulturową współczesnych realiów.

Aby zrozumieć mechanizmy związane z pracą dyskursu na polu edukacji, należy w pierwszym kroku zadać pytanie elementarne: czym jest dyskurs? Jest to bowiem jedno z tych pojęć, które za sprawą swojej niezwykłej popularności w obszarze wielu dyscyplin społeczno-humanistycznych przyjmowane

${ }^{1}$ P. Sosnowska, Arendt i Heidegger. Pedagogiczna obietnica filozofii, Kraków 2015, s. 279. 
i używane jest w sposób niewystarczająco jasny. W krwiobiegu społecznych debat stało się ono pojęciem nadużywanym, nadmiernie oczywistym, pozbawionym otoczki namysłu, ambiwalencji interpretacyjnej. Wymaga zatem uporządkowania i klarownego przedstawienia.

Szymon Wróbel twierdzi, że na polskim gruncie zakorzeniło się rozumienie dyskursu, w którym dominującą cechą jest jego systemowy i ponadjednostkowy charakter. Jest to efekt recepcji prac związanych z francuskim strukturalizmem². Dodaje jednak, że oprócz strukturalistycznego rozumienia dyskursu występują jeszcze co najmniej dwie kluczowe interpretacje, związane kolejno z socjolingwistyką i filozofią nauki. Ujmując rzecz w wielkim skrócie, można powiedzieć, że dla strukturalistów dyskurs jest nade wszystko systemem. Wróbel pisze w tym kontekście:

Prowadzi to do absolutyzacji bezosobowego systemu i marginalizacji roli podmiotu, której ukoronowaniem jest słynna teza o śmierci autora. Jest zatem tak, że „dyskurs mówi się sam", wykorzystując tylko osobę wypowiadającego. Badanie tekstu może być więc prowadzone bez odwoływania się do kategorii autora, która zastępuje szczegółowe badanie organizujących dyskurs reguł’.

Takie spojrzenie na dyskurs - pomijając pewien radykalizm powodujący rozmycie się roli podmiotu - pozwala dostrzec warunki, w jakich tworzy się określona narracja czy praktyka kulturowa. Pozwala to odpowiedzieć między innymi na pytania: czym myślimy? co jest punktem zapalnym i ramą naszego myślenia? Takie przytomne zdiagnozowanie środowiska myślenia jest - co może wydać się nieco paradoksalne - szansą na swego rodzaju emancypację podmiotu. Rozpoznanie statusu swojej wypowiedzi, źródła i ram myślenia jest bowiem z jednej strony uświadomieniem swojej ograniczoności, uwikłania w środowisko kulturowe, w jakim funkcjonujemy, historię, z drugiej zaś - pierwszym i koniecznym krokiem do wypracowania swego rodzaju autonomii myślenia. Jest to rodzaj niezależności uwarunkowanej świadomością zależności. Każda inna droga ma charakter pozorny, cechuje się naiwnością poznawczą. Ścieżki osiągania tak rozumianej autonomii myślenia są w sposób mocny związane z polem edukacyjnym. Dotyczą wszak samej relacji wychowawczej, w której zależność między wychowankiem a wychowawcą jest podstawową matrycą procesu edukacji, a konstruktywne przepracowanie tej relacji jednym z kluczowych elementów konstruktywnego rozwoju.

W drugim ujęciu interpretacyjnym dyskurs postrzega się jako paradygmat ${ }^{4}$. Jest to swego rodzaju reinterpretacja poprzedniego rozumienia dys-

${ }^{2}$ S. Wróbel, Metodologia, [w:] Szkoła jako fikcja i inne szkice z filozofii edukacji, red. S. Wróbel, R. Nawrocki, Kalisz - Poznań 2010, s. 65.

${ }^{3}$ Tamże, s. 66.

${ }^{4}$ Tamże. 
kursu. Głównymi bohaterami tego rozumienia Wróbel czyni takich badaczy, jak Michel Foucault i Jürgen Habermas. W świetle poglądów autora Archeologii wiedzy dyskurs

jest zestawem społecznych reguł wyznaczających formy wypowiedzi. Poszczególni aktanci, działający zawsze $\mathrm{w}$ ramach określonej formacji dyskursywnej, zdeterminowani są do wypowiadania określonych kwestii zgodnych z jego gramatyką - porządkiem 5 .

\section{Habermas zaś}

łącząc kategorie analizy wypowiedzi Searla i Austina z koncepcjamiSzkoły Frankfurckiej, (...) wypracował (...) oryginalną definicję dyskursu, który jest trwałym społecznym systemem determinującym poprawność wypowiedzi. Można zatem powiedzieć, że to nie świat opisujemy, lecz opis świata. Nieważne, jaka jest rzeczywistość, ważne, jaki jest jej opis. Dyskurs jest więc sposobem samoopisywania się kultury ${ }^{6}$.

Podobnie jak w pierwszej interpretacji, tak i tu dyskurs jest swego rodzaju matrycą, która wyznacza pole gier społecznych. Naruszenie tych reguł - próba wyjścia poza określony paradygmat - uwarunkowane jest podjęciem ogromnego wysiłku, graniczącego nierzadko z naruszeniem społecznego tabu. Ponadto, takie rozumienie dyskursu uświadamia w sposób dobitny, jak silny i kluczowy element zapośredniczający człowieka ze światem stanowi sfera językowa. Język, w tej perspektywie, jest nie tyle reakcją na rzeczywistość, ale to właśnie odbiór, czytanie rzeczywistości są wtórne wobec języka. Ponownie mamy tu do czynienia ze swoistą ambiwalencją relacji występującej na linii podmiot dyskurs. Z jednej bowiem strony, stopień uwikłania w symboliczną sferę kulturową odsłania jakiś rodzaj bezradności twórczej podmiotu wobec świata, z drugiej jednak strony świadomość siły performatywnej funkcji języka, kultury pozwala wypracować strategie mocnego, autorskiego opisu świata i twórczego bycia w nim. Droga to niełatwa, wymagająca przepracowania zależności i pokonania lęku przed wpływem na rzecz uruchomienia bardziej fortunnych dla naszego poczucia wolności strategii zarządzania całą siecią nici, w którą jesteśmy uwikłani. Jest to kolejne kluczowe wyzwanie dla edukacji.

I wreszcie ostatnia interpretacja dyskursu, w której traktuje się go przede wszystkim jako interakcję. Wróbel konstatuje:

W odróżnieniu od dotychczasowego rozumienia, dyskurs nie jest tu przede wszystkim korpusem tekstów, lecz wypowiedzią, której efektem jest interakcja - spotkanie dokonujące się w określonym kontekście. Dyskurs jest tym, co stwarza przestrzeń interakcji ${ }^{7}$.

\footnotetext{
5 Tamże.

6 Tamże, s. 68.

7 Tamże, s. 69.
} 
W nurcie tym pojawia się najczęściej osoba T.A. van Dijka, dla którego dyskurs ,jest strukturą werbalną, zespołem mechanizmów poznawczych oraz sposobem działania i interakcji w społeczeństwie" ${ }^{\prime 8}$. Jest on tu pojmowany jako gramatyka przestrzeni komunikacji zachodzącej między ludźmi, jako swoista siła ustalająca reguły komunikacji.

Podsumowując, Wróbel twierdzi, że dyskurs można traktować w trojaki sposób, jako: werbalizację myśli; formację kulturową rządzącą się określonymi prawami oraz przestrzeń spotkania wypowiadającego i słuchacza9. Według tego autora, współczesne rozumienie dyskursu jest splotem tych trzech interpretacji.

We wszystkich wymienionych tradycjach proponujących odmienne ujęcia dyskursu, jedna kwestia jest niewątpliwie wspólna: istota relacji zachodzącej pomiędzy podmiotem a siłami, które go konstytuują. Powtórzmy zatem: istotą wyłaniania się władzy nad sobą jest przepracowanie tego napięcia i trudu z niego wynikającego. Stanowi to jedno z ważniejszych wyzwań edukacyjnych. Pojawia się tu pytanie: jaka edukacja stwarza szansę na ucieczkę od absolutyzacji systemu na rzecz wolności podmiotu? Stawka tych zmagań jest dla edukacji i pedagogiki kluczowa z co najmniej kilku względów. Po pierwsze, kształt relacji pomiędzy podmiotem a dyskursem jest związany z podstawowymi dla pedagogiki pytaniami antropologicznymi: kim jest człowiek? jaki jest jego status w świecie? w jakiej mierze jest w stanie świat rozumieć, a w jakiej zaledwie bezwiednie obraca się w trybach dyskursów, wobec których jest całkowicie bezradny? Jest to zatem pytanie o wolność podmiotu. Podstawowym polem, na którym ta kwestia się rozgrywa jest niewątpliwie obszar edukacji. Po drugie, zdolność rozumienia świata otwiera pole reinterpretacji, dekonstrukcji, negocjowania znaczeń tworzących podstawowy korpus pojęciowy dla pedagogiki i edukacji. Dzięki temu otwiera się możliwość rzetelnej pracy dyskursywnej, interpretacyjnej, która może pomóc budować pole edukacyjne w sposób głębszy, bardziej rozumny, adekwatny do możliwości, jakie tkwią w procesie edukacji. Jest to ważny impuls, który pozwala uchronić nas przed zabiegami manipulacji, indoktrynacji, urzeczowienia podmiotu.

Wracamy zatem do pytania o możliwości pracy z pojęciami, jakie są podstawowym elementem każdego dyskursu kulturowego, każdego dyskursu pedagogicznego. Paulina Sosnowska, interpretując myśl H. Arendt, pisze w tym kontekście:

nasza pojęciowość kryje w sobie fenomeny, które musimy odsłonić. Arendt zakłada, że historia jest przestrzenią, w której różne formy pojawiają się jako rozpoznawalne

\footnotetext{
8 Tamże, s. 70.

9 Tamże, s. 75.
} 
fenomeny, nie zaś procesem, w którym wszystko może przekształcić się we wszystko, czemu towarzyszy - jej zdaniem - pomieszanie pojęć (definiowanych teraz przez każdego na własny użytek) i przesłonięcie odpowiadających im doświadczeń ${ }^{10}$.

Odkrywanie na nowo pojęć, który to zabieg może być początkiem budowania określonego dyskursu, nie wynika zatem - jak już mówiliśmy - z fetyszyzacji źródeł, nie jest strategią z gruntu konserwatywną, której podstawowym atutem określonego rozumienia pojęć jest ich zakorzenienie w tradycji. Słuszności takiej pracy etymologicznej szukać należy, według mnie, w dwóch rodzajach argumentów. Po pierwsze, istnieje pewien poziom funkcjonowania danego pojęcia, który odsłania jego wieloznaczność, Znakomicie ujął to Roberto Esposito, odnosząc się do kluczowych pojęć z zakresu filozofii polityki. Pisze on tak:

element metafizyczny nowoczesnej filozofii politycznej (grożący umieszczeniem jej w kole bez wyjścia) polega przede wszystkim na założonej uprzednio dominacji obszaru znaczenia nad sferą sensu, tendencji do redukowania horyzontu sensu wielkich słów tradycji politycznej do ich najbardziej bezpośredniego i oczywistego znaczenia. To tak jakby filozofia ograniczała się do powierzchownego, bezpośredniego podejścia w stosunku do kategorii politycznych, tak jakby była niezdolna do przemyślenia ich na wskroś i skradania się za nimi, by na powrót wejść w ich ukryte zakamarki - w przestrzeń ich bycia dotąd niepomyślaną. Każde pojęcie polityczne ma swoją jasną, od razu uchwytną część, ale również obszar zaciemniony, niejasny, smugę cienia, z której ta oczywistość ujawnia się poprzez kontrast ${ }^{11}$.

Oczywistość ta spłaszcza pojęcia, pozbawia tkwiącego w nich potencjału, nie pozwala właściwie pracować im w symbolicznym polu kultury, również edukacji. Według Esposito,

wszystkie nasze wielkie słowa z naszej tradycji politycznej - demokracja władza, suwerenność - mają w swojej głębi, u swoich źródeł, ten pierwiastek sprzeczności, aporetyczność, tę wewnętrzną walkę, która uniemożliwia ich zredukowanie do linearności powierzchownych znaczeńn ${ }^{12}$.

Odsłanianie etymologii pojęć nie jest zatem pracą sentymentalną. Jej sensu należy raczej szukać w tej dynamice i aporetyczności, głębi, jaką się za sprawą tej pracy wydobywa. Podobnie rzecz się ma z pojęciami kluczowymi dla edukacji. Holenderski filozof edukacji Gert Biesta w pracy Beautiful risk of education dokonuje takiej wiwisekcji, reinterpretacji, odsłonięcia potencjału pojęć kluczowych dla dyskursu pedagogicznego. Stosując opisaną wyżej strategię, bierze

${ }^{10}$ P. Sosnowska, Arendt i Heidegger, s. 284.

${ }^{11}$ R. Esposito, Pojęcia polityczne. Wspólnota, immunizacja, biopolityka, przekł. K. Burzyk, M. Burzyk, M. Surma-Gawłowska, J.T. Ugniewska-Dobrzańska, M. Wrana, Kraków 2015, s. 82.

12 Tamże, s. 82-83. 
na swój warsztat takie między innymi pojęcia, jak: kreatywność, komunikacja, nauczanie, uczenie się, emancypacja, demokracja. Biesta dokonuje pracy etymologicznej, interpretacyjnej, pozwalającej wydobyć z danego pojęcia to, co najbardziej wpłynie na niebanalne rozumienie i doświadczanie świata. Zarówno Esposito, jak i Biesta piszą w duchu obrońców współczesnego świata przed jego instrumentalizacją, spłaszczeniem, urzeczowianiem, banalizacją. Pierwszym, być może najważniejszym, krokiem jest w tym wyzwaniu praca dyskursywna właśnie. Na przykład, Biesta szuka sposobu uchwycenia pojęcia kreatywności, który przekracza obecne psychologiczne rozumienie tego pojęcia. Dzięki impulsom płynącym choćby z pism Emmanuela Levinasa ${ }^{13}$ czy Johna Caputo $^{14}$, próbuje wyjść poza utarte, związane z kulturą Zachodu rozumienie kreatywności. Aby było to możliwe, wykorzystuje dystynkcję zaproponowaną przez Caputo, rozróżniającą mocną metafizyczną koncepcję kreacji (strong metaphysical conception of creation) i tak zwane słabe pojeccie kreacji (weak notion of creation), której esencją jest wołanie o bycie w świecie. Biesta optuje za drugim pojęciem. Jest to zatem pomysł, w którym przekraczamy zarówno techniczne, nadmiernie psychologiczne pojęcie kreacji, jak i przesadnie abstrakcyjne, metafizyczne, dalekie od egzystencji człowieka pojęcie kreacji.

Biesta, podobnie jak Hannah Arendt, chce zatem zaproponować dyskurs, który pozwala przybliżyć człowieka światu i nadać naszej sytuacji egzystencjalnej podmiotowość i głębię. Szuka sposobów, znów podobnie jak Arendt, definiowania wolności jako dyspozycji uruchamiających jakiś nowy początek zdarzeń. Biesta pisze: „wiemy już co istnieje, natomiast winniśmy być zainteresowani sposobami, jakimi powinniśmy się posłużyć, aby móc uruchomić nowe początki zdarzeń i ich twórców"15. Aby tego dokonać, przytoczmy raz jeszcze: konieczna jest praca nad siatką pojęciową dotyczącą edukacji i próba takiego naświetlenia używanych w pedagogice pojęć, aby stały się one sprzymierzeńcem wyżej opisanej egzystencji. Aby zrozumieć tę strategię, spójrzmy choć pobieżnie na to, jaką pracę interpretacyjną, konceptualną wykonuje Biesta względem pozostałych pojęć, składających się na strukturę książki The beautiful risk of education. I tak, omawiając pojęcie komunikacji, Biesta, odnosząc się szczególnie do myśli Deweya, próbuje wydobyć z niego nade wszystko jego potencjał interakcyjny, partycypacyjny, pokazując, że istotą komunikacji jest nadawanie znaczeń i dokonywanie interpretacji. Pisze zatem:

Będę argumentował $\mathrm{w}$ tym rozdziale, że dominujące rozumienie komunikacji jest niewystarczające, niezadowalające, ponieważ opiera się ono na modelu transferu in-

${ }^{13}$ Zob. E. Levinas, Of God who comes to mind, Stanford 1998.

${ }^{14}$ Zob. J.D. Caputo, The weakness of God: A theology of the event, Bloomington and Indianapolis 2006.

${ }^{15}$ G. Biesta, The beautiful risk of education, London 2013, s. 4. 
formacji z jednego umysłu do drugiego, podczas gdy należy ją raczej rozumieć jako proces wytwarzania znaczeń i interpretacji ${ }^{16}$.

Tak rozumiana komunikacja staje się ważną podstawą procesu edukacji, procesu uczenia się. Kolejne omawiane pojęcia także poddawane są interpretacji, która pozwala je zdynamizować, wydobyć z zastygłego, niesłużącego dynamice rozwojowej, letargu. Pojęcie nauczania wiąże się na przykład z niebanalnym rozumieniem samego nauczyciela. Biesta pisze: „powinniśmy rozumieć nauczyciela jako kogoś, kto w najbardziej ogólnym sensie wprowadza coś nowego do sytuacji edukacyjnej, coś, czego jeszcze nie było"17. Posługuje się w tym miejscu koncepcją konstruktywistyczną, lokując jej początki już u Sokratesa i Platona, co nadaje konstruktywizmowi głębszego znaczenia, które trudne jest do wydobycia posługując się tylko współczesnymi, psychologicznymi koncepcjami konstruktywistycznymi.

Kolejne pojęcia poddane pracy interpretacyjnej, to: uczenie się, emancypacja, demokracja, wirtuozeria.

W analizie pojęcia uczenia się Biesta pozbawia go przyjętej powszechnie neutralności, naturalności, nadając mu charakter polityczny. Pojęcie emancypacji omawiane jest w odniesieniu do koncepcji francuskiego filozofa Jacquesa Rancière'a. Podstawowym zyskiem wynikającym z tego zapożyczenia jest przesunięcie akcentu w procesie emancypacji z czegoś co zewnętrzne wobec podmiotu, w stronę samego podmiotu. Biesta pisze w tym kontekście:

Takie rozumienie emancypacji nie opiera się już na (możliwości) „potężnej interwencji" z zewnątrz, ale raczej wykluwa się w sytuacjach upodmiotowienia, w których jednostki opierają się istniejącej tożsamości i zaczynają mówić na własnych warunkach ${ }^{18}$.

To kolejna próba przeformułowania jednego z kluczowych współcześnie pojęć w stronę rzeczywistego upodmiotowienia. Strategia ta znana jest z koncepcji wchodzących w skład tak zwanej pedagogiki krytycznej.

Omawiając pojęcie demokracji, holenderski filozof odwołuje się do koncepcji Hanny Arendt. Odnosi się jednak do niej krytycznie i oferuje zgoła odmienną propozycję relacji pomiędzy demokracją a edukacją, bo ten wątek szczególnie go interesuje. Podstawową osią różnicującą myśl Arendt i propozycję Biesty jest to, że dla Arendt demokracja i pojęcie wolności z nią związane nie przynależą i nie mogą przynależeć do obszaru edukacji. Dla autorki Kondycji ludzkiej proces edukacji ulokowany jest w domenie przygotowania do demokracji, nie może natomiast sam nią być. W tym sensie, wolność polityczna nie może być koncepcją edukacyjną. Takie rozumienie prowadzi do

\footnotetext{
16 Tamże, s. 26.

17 Tamże, s. 44.

18 Tamże.
} 
rozłączenia edukacji i polityczności, na co nie zgadza się Biesta. Według niego, rozdział demokracji i edukacji, polegający na tym, że demokracja ma być zaledwie efektem edukacji, a nie być z nią sprzężona, wyjaławia proces edukacji z potencjału politycznego, który byłby szansą na rzeczywiste kształcenie obywatelskie.

Ostatnie pojęcie analizowane przez autora Beyond learning to pojęcie doskonałości, wirtuozerii (virtuosity). Biesta zastanawia się w kontekście tego pojęcia, na czym winna być oparta profesja nauczycielska. Wychodzi tu poza spór mieszczący się pomiędzy poglądami traktującymi tę profesję jako sztukę (art) bądź opartą na mechanizmach ulokowanych w nauce (science). Dla Biesty jest czymś oczywistym, że profesję nauczycielską należy traktować jako sztukę, pytaniem pozostaje: jakim rodzajem sztuki nauczanie obecnie jest i jakim być powinno. Aby w sposób niebanalny odpowiedzieć na nie, holenderski filozof odwołuje się do dystynkcji zaproponowanej przez Arystotelesa na poiesis oraz praxis. W pierwszym przypadku mowa o działaniu, którego cel leży poza wykonywaną czynnością (poiesis), w drugim mamy do czynienia z sytuacją, w której cel leży w samym podejmowanym działaniu (praxis). Sięgnięcie do tego rozróżnienia pozwala wygenerować nowy, zupełnie zapomniany i niezgodny z powszechnie obowiązującymi dziś normami, ogląd profesji nauczycielskiej. Biesta pisze:

Rozróżnienie między poiesis a praxis pomaga nam dostrzec, że nauczyciele nie tylko potrzebują wiedzy o tym, jak robić rzeczy (techne), ale także, i przede wszystkim, potrzebują praktycznej mądrości (phronesis), aby ocenić, co należy zrobić19.

Takie spojrzenie na zawód nauczyciela jest radykalnie niewspółmierne do współczesnych strategii ewaluacji pracy pedagogicznej, którym przyświeca idea produkcji, której Biesta w sposób jednoznaczny się przeciwstawia.

Praca mająca na celu reinterpretacje pojęć, wydobycie z nich ambiwalencji, dynamiki jest pracą trudną i ryzykowną. Bezpieczniej pozostać w koleinach poznawczych dających iluzoryczne poczucie kontroli świata. W takiej sytuacji proces edukacji staje się jednak martwy. Odtwarza się w nim puste rytuały, konwencje. W tak skonstruowanej rzeczywistości edukacyjnej pewną codziennością staje się paraliż myślenia i sądzenia, brak odwagi poznawczej. Aby edukacja stała się procesem rzeczywiście służącym rozwojowi wyobraźni, niezależności, myślenia krytycznego, rozumianego jako zdolności ustanawiania warunków możliwości zaistnienia czegoś innego, nowego, musi - jak głosi tytuł książki Biesty - rozsmakować się w podejmowaniu ryzyka. Ryzyko jest tu pojęciem kluczowym. Można bowiem powiedzieć, że analiza wybranych, kluczowych pojęć z dziedziny edukacji wiąże się z ryzykiem. W polity-

\footnotetext{
19 Tamże, s. 8.
} 
ce oświatowej, praktyce edukacyjnej - w ich retorycznej warstwie - nie podejmuje się tak pojętego ryzyka. Jest to trudne z wielu względów. Jednocześnie nie rezygnuje się z tych pojęć. Dokonuje się ich zawłaszczenia, spłaszczenia, instrumentalizacji. Praca archeologiczna, polegająca na ciągłym ożywianiu znaczeń, jest jednym z kluczowych zadań, jakie stoją przed współczesną pedagogiką. Tworzy to punkt wyjścia dla wszelkich działań edukacyjnych.

\section{BIBLIOGRAFIA}

Biesta G., The beautiful risk of education, Taylor \& Francis LTD, London 2013.

Caputo J.D., The weakness of God: A theology of the event, Indiana University Press, Bloomington and Indianapolis 2006.

Esposito R., Pojęcia polityczne. Wspólnota, immunizacja, biopolityka, przekł. K. Burzyk, M. Burzyk, M. Surma-Gawłowska, J.T. Ugniewska-Dobrzańska, M. Wrana, Towarzystwo Autorów i Wydawców Prac Naukowych Universitas, Kraków 2015.

Levinas E., Of God who comes to mind, Stanford University, Stanford 1998.

Sosnowska P., Arendt i Heidegger. Pedagogiczna obietnica filozofii, Towarzystwo Autorów i Wydawców Prac Naukowych Universitas, Kraków 2015.

Wróbel S., Metodologia, [w:] Szkoła jako fikcja i inne szkice z filozofii edukacji, red. S. Wróbel, R. Nawrocki, Wydział Pedagogiczno-Artystyczny UAM w Kaliszu, Kalisz - Poznań 2010. 